\title{
Human Dignity during the Period of Economic and Social Crisis in Greece
}

\section{Chrysanthi Katseli}

\author{
Economist, MSc in Applied Pedagogy, University of Athens, Greece
}

Email: katselichrysanthi@gmail.com

Vassilis Pantazis

Associate Professor, University of Thessaly, Greece

Email: pantazisv@uth.gr

\section{Kyriaki Gounela}

Economist, MSc in Economics of Health, Hellenic Open University, Patra, Greece Email: kikhgounela@hotmail.com

\section{Doi:10.5901/mjss.2016.v7n4p}

\section{Abstract}

This research paper examines the repercussions of the economic and social crisis on the dignity of Greek citizens. In particular, convenience non - probability sampling was applied by means of a questionnaire distributed to Viotia (Boeotia), Attica, Kefallinia, Thessaloniki, Evia (Euboea) and Evritania, from 20th November 2014 to 20th February 2015 to a sample of 124 people. With the use of SPSS (Statistical Package for Social Science) and checking the Pearson's r Correlation Coefficient we concluded that there is a Moderately Positive Correlation between "Economic Crisis" and "Insult to Dignity". According to Coefficient of Determination $R^{2}$ (R-Square) it was revealed that $25 \%$ of the total variance of "Insult to Dignity" is due to "Economic Crisis", while $60.5 \%$ is due to reductions that have occurred in the "Incomes" of Greek citizens as a result of the economic and social crisis of recent years. Finally, the Multiple Regression Analysis indicated the existence of a linear relationship between "Insult to Dignity" and "Economic Crisis" $(Y=a+0.433 X)$, where the coefficient $b$ is Positive and Moderately Significant, and between "Insult to Dignity" and "Income" $(Y=a+0.608 X)$, where the coefficient $b$ is Positive and Strongly Significant.

Keywords: Human Dignity, economic and social crisis, poverty and social exclusion, income, living conditions.

\section{Introduction}

Due to the economic policy of internal devaluation, the Greek economy has remained for the eighth year (2008-2016) in deep recession and increased unemployment without visible signs of recovery in the aggregate. The result of this policy is ultimately for the Greek economy to adjust deficits (both fiscal and external) through the shrinking of its productive capacity, work depreciation and a considerable expansion of poverty and social exclusion (INE-GSEE, 2013). As a consequence, the Greek society is experiencing a long period of a productive - social sedimentation and humanitarian crisis along with a restructuring of the social and class formation driven by the intensity of social and income inequalities which contribute to social crash unemployment as well as transformation of the welfare state into a charity state (Caritas Europa, 2013). Within the general economic and social crisis in Greece over the recent years, the ultimate "challenge" that has emerged is also most obvious "...the protection of human dignity..." (Tsevrenis, 2012).

\section{Conceptual Orientation}

\subsection{Economic and social crisis in Greece: Poverty and Social Exclusion}

To calculate total poverty and the effectiveness of the policies employed to combat it, it is important to answer the question "who are the poor" (Andriopoulou, Papadopoulos \& Tsakloglou, 2013). A prominent problem in this process is whether to select objective (e.g. real income of individuals) or subjective terms (where people are self-classified as poor or non-poor, being the best judges of their individual income situation) (Andriopoulou \& Tsakloglou, 2010). 
In the literature we find several definitions of poverty, such as the definition adopted in the Copenhagen Conference on Social Development organized by the UN in 1995. According to this, "poverty is a condition characterized by severe deprivation of basic human needs such as food, drinking water, basic sanitation, health services, shelter, education and information. It depends on income as much as the access to services" (Balourdos, 2012, p. 25).

From the various definitions of poverty that are reported by the literature, we usually arrive at two general categories (undoubtedly accompanied by overlap and controversy): absolute and relative poverty, which involve different measures and have received different treatment from the state and social policy. Absolute poverty is defined as a situation into which an individual falls when he or she can barely survive (survival benchmark), while he or she finds it difficult to access resources such as food, shelter, education and health. The World Bank sets an absolute poverty limit equal to the sum of $\$ 1.25$ per day, valid for 1.2 billion people, most of whom have incomes far less than even one/a dollar a day (Andriopoulou et al., 2010. Pantazis, 2013).

On the other hand, the poverty measurement most widely used - albeit most problematic - today is based on the definition of relative poverty that ranks as poor all household members who have money income lower than $60 \%$ - or sometimes $50 \%$ or $40 \%$ - of the median and sometimes of the average income of/in the entire country (Andriopoulou et al., 2010). According to this, relative poverty is no more than the reflection of the degree of inequality in the income distribution of an economy, instead of the minimum income below which the ability of individuals to survive is hampered (survival benchmark) (Lamprinidis, Maniatis, Mpasiakos, Economou, Papadopoulou \& Passas, 2010).

The index "at risk of poverty and social exclusion", used in the context of "Europe 2020" strategy, was significantly increased in Greece by $27.6 \%$ in 2009 to $31 \%$ in 2011. The gap opened by 2.7 percentage points between 2010 and 2011. In 2011 it even reached 26.1\%, representing more than 3.4 million people, while the European average was $23.4 \%$. At the same time, between 2010 and 2011 there was also a marked increase in the other two poverty indicators - people experiencing severe material deprivation and those living in households with very low work intensity (Eurostat, 2012a).

With respect to pensioners, the risk of poverty has increased since the earliest years of the onset of the crisis. In 2011, the share of pensioners in the poor population was significantly reduced, but this was mainly due to the dramatic fall suffered by the poverty threshold in Greece. The percentage of those who were over 65 and at risk of poverty was $21.3 \%$ in 2010, higher than the average in the EU-27 (16\%), while it was also higher than that of the working population (19\%) (Eurostat, 2012b). The data showed a sizable increase (more than two percentage points) in the poverty rate for this age group between 2010 and 2011. Elderly women in Greece had a higher risk of poverty (25.2\%) than the respective rate for older men (21.7\%) (Eurostat, 2012c). Older women in Greece also had a higher rate of material deprivation than older men, a difference of almost 5 percentage points in 2010 (Social Protection Committee, 2012).

Most of these approaches adopt a unidimensional concept of poverty, according to which income falls below a certain threshold (Watts, 1968). However in an abundance of scientific texts, at both a theoretical and an empirical level, it was supported that a multivariate measurement of poverty was needed; apart from the position of the individual in relation to the poverty line, one should take into account a number of additional specific parameters, such as health, education, life expectancy, access to public goods and markets etc. This way, the multidimensional poverty measurement is closely linked to the concept of social exclusion (Andriopoulou et al., 2013).

Therefore, the term social exclusion is now used to complement or even substitute that of income poverty. It does not only contain the deviation from an adequate or socially acceptable income, but also the deduction in the democratic and legal system, the labor market, the welfare system, the family and the community, which could contribute to the political, economic, interpersonal and social participation and integration of people in society (Feronas, 2004), resulting in their characterization and consequent marginalization. In this sense, the core of the concept of social exclusion is to deprive the individual of fundamental political, economic and social rights (Retinioti \& Mantziou, 2010).

On 21st November 2013, the Committee on Economic and Monetary Affairs (ECON) was assigned with the preparation of an investigation report on the role and the operations of the Troika in the four countries that have been subject to fiscal adjustment programs: Greece, Ireland, Portugal and Cyprus in order to identify the social repercussions of these programs and their impact on employment. Among other factors, there was expressed concern about the fact that the adjustment programs and economic crisis led to increased unemployment, job losses and cuts in access to health services and medicines, while at the social level, an increase in poverty and risk of social exclusion has been observed; moreover, all of the above were not accompanied by measures to protect the most vulnerable groups (European Parliament, 2014).

The Report on the impact of the crisis on the access of vulnerable groups to healthcare by the European Parliament in 2013 stated that the provision of healthcare faces significant challenges. The cuts that have been made, whether concerning services or social benefits, are affecting both people who need care and those who provide it; this has contributed to the prevention of early access to care, thus requiring more expensive and urgent care services later. 
This can also result in the interruption of therapy treatments and may involve absence from work or, an even more serious outcome: adverse evolution of the medical condition. Moreover, the number of homeless people or people who have temporary housing has increased in some member states, to the extent that many of them do not have permanent access to healthcare, while there are indications that some EU citizens do not have access to treatment in another member state (European Parliament, 2013).

The NGO Mission (Church of Greece) refers to a rapid increase in the number of people who addressed to the parish care centers of churches in Athens to secure their daily portion of food, reaching in April 2011 the number of 5000 beneficiaries, of which $60 \%$ were Greek (Caritas Europa, 2013). According to research conducted by the Foundation "Stavros Niarchos" in 152 schools in the country (year 2012-2013), one in four (27\%) students felt food insecure with hunger evident (Bourikos \& Sotiropoulos, 2014).

The NGO "Scale-Agency for the Development of Social Capital" says the rates of homeless or temporary-housing populations are soaring. The size of this population, on the one hand, to converge with the highest average European level, while, on the other hand, it has broadened to include non-specific vulnerable groups (substance-addicted, undocumented immigrants) as well as newly poor and indebted households (Bourikos et al., 2014). The EU Network of Independent Experts on Social Inclusion concludes that policies in relation to housing and homelessness have not strengthened during the past few years and are considered to have weakened (Frazer \& Marlier, 2012).

Moreover, the reference to issues of survival made by people using the social emergency helpline of the National Centre for Social Solidarity (EKKA) increased from 14\% in 2009 to 19.4\% in 2011. Another manifestation of the impact of the crisis is the data regarding the use of the depression helpline from the University Research Institute of Mental Health (EPIPSI): the percentage of calls with direct or indirect reference to the economic crisis has increased from $1.8 \%$ in the period July to December 2008 to $8.4 \%$ and $26.9 \%$ over the same period in 2009 and 2010 respectively (Bourikos et al., 2014). Finally, the Greek Organization Médecins du Monde emphasizes the increasing percentage of Greeks now seeking medical care from the street clinics (Kentikelenis, Karanikolos, Papanicolas, Basu, McKee \& Stuckler, 2011).

\subsection{Human Dignity}

Human dignity is not an individual right, but the whole or the "sum" of human rights. Therefore it is related to human rights, since its defense constitutes the fundamental principle of human rights by putting the individual at the center of interest (Phillips, 2011). However, it is not just a euphemism for all human rights, nor does it simply describe human rights or a systematic form of violation of individual rights. Sometimes it is interpreted as a middle principle between other ethical principles (Kemp, Rendtorff \& Johansen, 2000), aforetime as the right to have human rights, expressing the fundamental right of everyone to be a citizen of a State and body of equal rights (Arendt, 1956 / 2006). However an approach that appears to be promising is the idea of human dignity to be considered as the basis of human rights. This view accepts an internal connection between dignity and rights in such a way as to give people rights since they have dignity, where the content of dignity is governed by rights (Gewirth, 1992). These rights are based on a common and universal system of values, which defends the inviolability of life and thus provides a context for building a human rights system with internationally recognized standards and norms.

Human dignity is central to the United Nations Charter (1945) and the Universal Declaration of Human Rights (1948), the International Covenant on Economic, Social and Cultural Rights (1966), the International Covenant on Civil and Political Rights (1966), the UNESCO Universal Declaration on Bioethics and Human Rights (2005) and in many other instruments of international and regional institutions, maintaining a prominent position on the Rights Theory (Phillips, 2011).

Although human dignity is considered to be a key component of the culture of a society, it is a manifold and complex concept since there is no established common perception as to how it ultimately determines its components in any legal system. Therefore, its interpretation conspicuously varies within each legal system, by often comprising -even for the same legal order- a variable component in space and time. It depends, therefore, on the distinct political and economic system, the structure of society, the spiritual and cultural tradition and religion (Delikonstantis, 1995). For this reason, and despite the fact that opinions on its content differ, historical periods have shown that it was not always selfevident that all men were dignity bodies, while the term has been invoked equally by socio-political systems that are in stark contrast to one another.

Human dignity is often referred to in combination with the values of free development of the individual, equality and social solidarity. Establishing itself sometimes as an individual right - aforetime with the validity of an objective legal rule serving as a behavioral endpoint and sometimes as an interpretative tool for finding fair and equitable solutions - proves to be a "vital weighting regulator of the limits of constitutionally protected rights and interests of all parties" (Tsevrenis, 
2012, p. 18). At times it is connected to the individual perception of the social state or used to establish the right to welfare and social security. The state has the task of ensuring the observance of human rights and the non-insult of human dignity by rendering the idea of human rights a principle of political and social justice. The state is a precondition for the realization of justice. It should therefore not only be a state of democracy and rule of law but also a constitutional social state of law (Wildfeuer, 2002).

The security and the preservation of human dignity as an "institutional policymaking tool" defines the meaning of "extreme poverty" as a combination of income poverty, poverty in terms of human development and social exclusion (Tsevrenis, 2012). It therefore identifies the causal relationship between poverty, perceived as all violations of fundamental rights, insults of human dignity and of that lack of freedom in government relations or other form of power and the false wealth produced of them, which prevents the free and dignified existence of the poor and generally complicates the possibility of development of human existence (Thielen, 2000). Inequality is an erosion of dignity, not only because it does not recognize the "inherent dignity of man", but also and above all, because it denies the conditions for all human persons to live with dignity. While dignity is more important to the human spirit than wealth, it requires material social welfare. It is the "survival tool that protects people from living under a decent level". It creates all the support and autonomy required to achieve the capabilities and the enjoyment of life opportunities that each one has chosen, to fulfill the potential of every individual. "So, to evaluate the inherent dignity of human beings a society, we must ensure that there are material conditions/prerequisites in which people can develop their skills and participate in shaping their society" (Phillips, 2011, p. 13).

The Conference of European Justice and Peace Commissions held an International Conference in Greece on "Human Dignity and Economic Crisis". As pointed out, the effects of the crisis in Greece were particularly intense and visible. People may not have access to employment and successful integration into society when they are homeless, have no income or are in need of treatment for physical or mental health issues. The crisis has not only been viewed as a political crisis, but also a moral and social crisis, which requires a radical change of direction to restore confidence, prioritizing clearly to people's needs, leading to inspire people to get involved again with democratic processes in order to build a Europe of democracy and solidarity (Comisión General de Justicia y Paz, 2014).

The findings of the report of five Caritas country organizations (Greece, Ireland, Italy, Portugal, Spain) prove beyond doubt that austerity measures are adversely affecting the lives of people living in poverty and leading many others to poverty and social exclusion for the first time (Caritas Europa, 2013).

\section{Research Goals and Methodology}

\subsection{Research Aim and Specific Goals}

The purpose of this research was to investigate the repercussions brought about by the economic and social crisis on the human dignity of Greek citizens. In particular, however, the survey sought to focus on the impact of the economic and social crisis on the preservation of the dignity of citizens in a social sedimentation climate and a humanitarian crisis, on the social policy pursued by the state and the importance of the welfare state in times of economic recession.

\subsection{Research Hypotheses}

Based on the above purpose and specific goals, the basic research hypothesis was set as follows:

"The "Economic Crisis" and more specific the reductions that have occurred in the "Incomes" of Greek citizens affects their "Dignity" in such an extent so that they feel that they have sustained an "Insult to their Dignity"."

More specifically, the survey sought to examine the extent to which participants have undergone an "Insult to Dignity" in the last period with respect to demographic characteristics such as gender, age, marital status, education level, employment, unemployment but also concerning income, living conditions, health condition and the social exclusion that they have suffered. 


\subsection{Methodology}

\subsubsection{Research Method and Questionnaire}

The questionnaire is the prominent data collection technique in the research of various sciences. The questions and instructions for answering the questions were designed, given and arranged in a way that the answers would ensure the requested information, but without leaving any margin of misinterpretation (Paraskevopoulos,1993).

Words or phrases that are characterized by ambiguity and inaccuracy were prevented, while questions psychologically and socially "painless" or neutral were selected, so that the subjects would feel more directly involved in the research, reducing their psychological resistance in order to respond with less hesitation and more spontaneity (Vamvoukas, 1991). For this reason, an anonymous questionnaire was used to ensure the privacy and confidentiality of any personal information and data to be recorded in it (Nova - Kaltsouni, 2006).

Measurements in many questions were made by using the five-point Likert scale, i.e. starting from the positive Very Much (1) to Not at All (5) and the positive Yes (1) to the negative No (2). At the same time, the opportunity was given to those who did not wish to answer a question, by selecting Don't Know / No Opinion (DK / NO).

\subsubsection{Sampling}

The sampling method used in the survey was "convenience" non-probability sampling, where the main feature is that each element of the population does not have the same and equal opportunity to be selected and included in the sample (Darviri,2009).

The survey was conducted in the period from $20^{\text {th }}$ November 2014 to $20^{\text {th }}$ February 2015. The questionnaires were distributed in the counties of Viotia (Boeotia), Attica, Kefallinia, Thessaloniki, Evia (Euboea) and Evritania. Then the collection, indexing, codification and statistical analysis of the results took place.

\subsubsection{Sample}

The surveyed accessible population concerned those members who were adults (i.e. over 18 years old). However, because of time and cost restrictions, the main "target-population" was designated as the residents of the county of Viotia (Boeotia), without excluding residents of the other counties.

The county of Viotia (Boeotia) produces $2 \%$ of GDP, the seventh $\left(7^{\text {th }}\right)$ highest in Greece, without presenting any particular change in the recent years. The per capita GDP of Viotia (Boeotia) reaches 34.3 thousand Euros, $78 \%$ higher than the national average and $145 \%$ of the average of EU-25, due to the high concentration of industries in the region. Therefore, it is a resourceful county, with a characteristic contradiction being that despite the industrial development, it has one of the highest rates of unemployment and underemployment (part-time jobs) in the country (Chamber of Viotia, 2012).

The sample size used in the survey was (124) people who live in Viotia (Boeotia), Attica, Kefallinia, Thessaloniki, Evia (Euboea) and Evritania.

\subsubsection{Sample's Features}

Table 1: Demographic Characteristics

\begin{tabular}{|l|c|c|}
\hline & N & $\%$ \\
\hline SEX & & \\
\hline Male & 49 & 39,5 \\
\hline Female & 75 & 60,5 \\
\hline Total & 124 & 100 \\
\hline AGE & & \\
\hline $15-24$ & 19 & 15,3 \\
\hline $25-34$ & 24 & 19,3 \\
\hline $35-44$ & 24 & 19,3 \\
\hline $45-54$ & 23 & 18,6 \\
\hline $55-64$ & 23 & 18,6 \\
\hline $65+$ & 11 & 8,9 \\
\hline Total & 124 & 100 \\
\hline
\end{tabular}




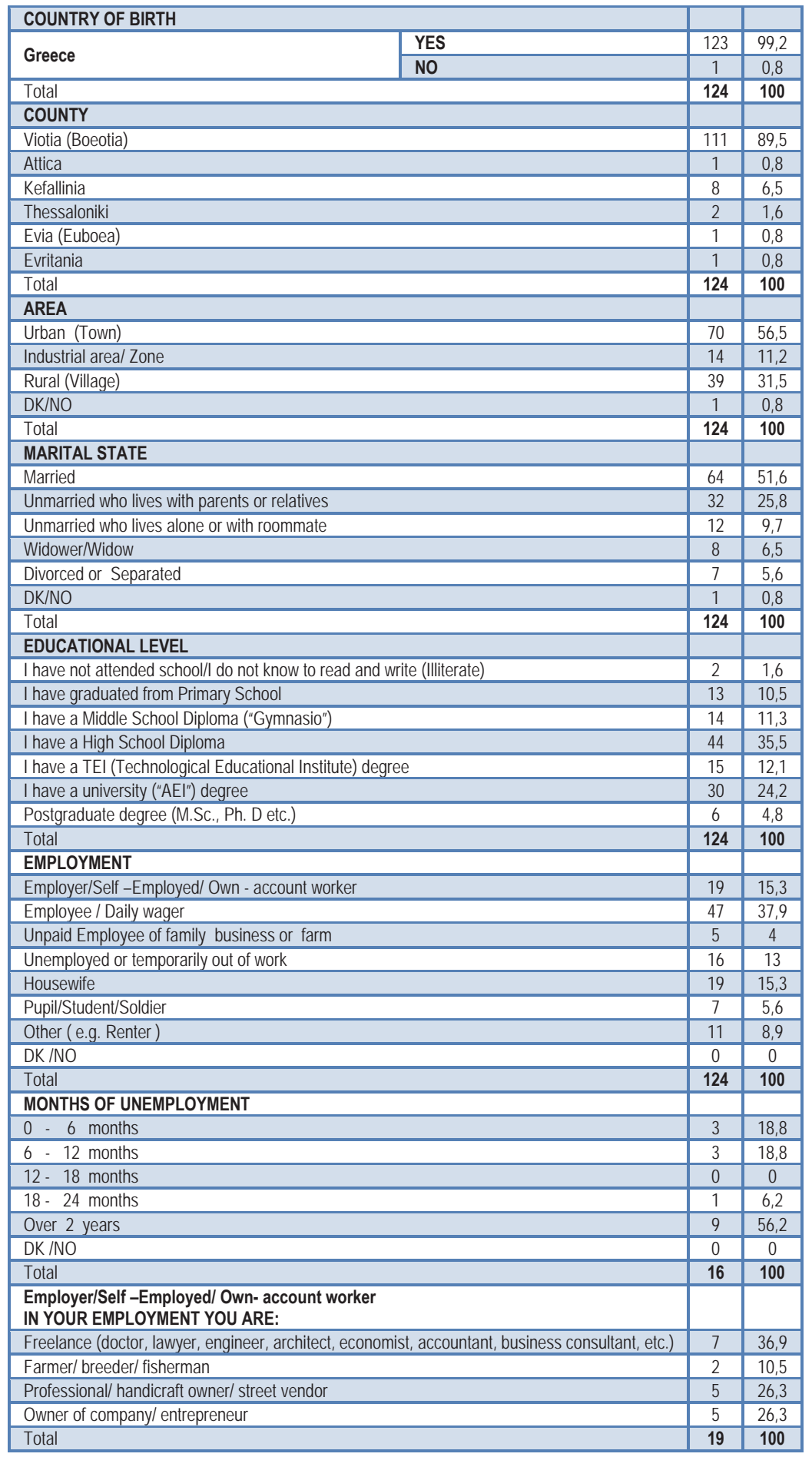


As seen in Table 1, the survey involved more women (60.5\%), while there were no significant differences concerning the age group of the participants. The vast majority were born in Greece and were residents of Viotia (Boeotia). More than half were married (51.6\%) and had completed up to secondary education (58.9\%), while higher education made up $41.1 \%$ of the participants. Regarding their occupation, most belonged to the economically active population, with salaried or daily wage employees comprising $37.9 \%$, followed by housewives (15.3\%) and unemployed (13\%).

\subsection{Statistical Analysis}

\section{"Insult to Dignity"}

In the questionnaire, the dimension "Dignity" is negatively charged, since the questions are relating to the "Insult to Dignity" that people have suffered during the economic crisis. Therefore, the results as derived from the statistical analysis are:

- The Cronbach's alpha coefficient is a reliability index that measures the internal consistency and coherence of multidisciplinary variables. The dimension "Insult to Dignity" valued 0.782 , while the other dimensions valued 1 , which indicates that the scale used was reliable and therefore the correlation between individual variables was higher (Nova - Kaltsouni, 2006).

- The Pearson's r Correlation Coefficient expresses the trend and the intensity of regression and is used to determine whether and to what extent two variables are correlated. The range of values for the coefficient $r$ is from -1 to +1 , with the first showing a perfect negative correlation or linear relationship, where the variables are moving in the opposite direction and the second a perfect positive or linear relationship between two variables where the variables are moving in the same direction. The significance level is defined as $5 \%$ (or 0.05 ). Therefore, the case where $(p \leq 0.05)$ demonstrates that there is a statistically significant difference between the average of the population and the predetermined value at this level of significance (Emvalotis, Katsis, \& Sideridis, 2006). The conducted survey produced the figures shown in Table 2:

Table 2: Correlation Coefficient Pearson r

\begin{tabular}{|c|c|c|c|c|}
\hline \multicolumn{5}{|c|}{ Correlation Coefficient Pearson $r$} \\
\hline \multicolumn{2}{|l|}{ Correlated Variables } & $r$ & $p$ & Correlation \\
\hline \multirow{7}{*}{$\begin{array}{l}\text { "Insult } \\
\text { to } \\
\text { Dignity" }\end{array}$} & Economic Crisis & 0,456 & 0,000 & \multirow{2}{*}{ Positive Moderate } \\
\hline & Months of unemployment & 0,468 & 0,05 & \\
\hline & Do not seek care because of economic weakness & 0,368 & 0,000 & \multirow{4}{*}{ Positive Low } \\
\hline & Lack of Money & 0,326 & 0,000 & \\
\hline & Lack of Social Security & 0,255 & 0,004 & \\
\hline & Health Condition & 0,153 & 0,005 & \\
\hline & Age & $-0,180$ & 0,046 & Negative Low \\
\hline Lack of Money & \multirow{4}{*}{ Health Condition } & 0,485 & 0,000 & \multirow[t]{2}{*}{ Positive Moderate } \\
\hline Lack of Social Security & & 0,420 & 0,000 & \\
\hline Income & & 0,302 & 0,05 & \multirow{3}{*}{ Positive Low } \\
\hline \multirow{2}{*}{ Living Conditions } & & 0,302 & 0,007 & \\
\hline & Social Exclusion & 0,293 & 0,009 & \\
\hline
\end{tabular}

As seen from the above table there is a Moderately Positive Correlation (positive linear correlation) between "Insult to Dignity" and "Economic Crisis" and between "Insult to Dignity" and "Months of Unemployment".

- Based on the Means Deviation Test (T-test), it can be evaluated if a mean is different from a parameter of the population or if there is a difference between two means of specific variables of the sample (Nova Kaltsouni, 2006). The deviation of the means test was related to a desired confidence interval of $95 \%$, while it should be stressed that the questions related to "Dignity" are negatively defined as "Insult to Dignity" with mean 1. More specifically, in relation to the demographic characteristics, the following were observed: 
Table 3: Means Deviation Test (T-test)

\begin{tabular}{|c|c|c|c|c|}
\hline \multicolumn{5}{|l|}{ Means Deviation Test (T-test) } \\
\hline \multicolumn{2}{|l|}{ "Insult to Dignity" } & Mean & $p$ & Greater Insult \\
\hline \multirow{2}{*}{ Sex } & Male & 1,41 & \multirow{2}{*}{0,04} & \multirow{2}{*}{ Women } \\
\hline & Female & 1,37 & & \\
\hline \multirow{2}{*}{ Age } & $15-54$ & 1,5771 & \multirow{2}{*}{0,023} & \multirow{2}{*}{$\begin{array}{l}(55-65+) \\
\text { years old }\end{array}$} \\
\hline & $55-65+$ & 1,4415 & & \\
\hline \multirow{5}{*}{ Marital State } & Married & 1,34 & \multirow{5}{*}{0,05} & \multirow{5}{*}{ Divorced or Separated } \\
\hline & Unmarried who lives with parents or relatives & 1,47 & & \\
\hline & Unmarried who lives alone or with roommate & 1,58 & & \\
\hline & Widower/ Widow & 1,38 & & \\
\hline & Divorced or Separated & 1 & & \\
\hline \multirow{9}{*}{ Educational Level } & Illiterate & 1,5 & \multirow{9}{*}{0,03} & \multirow{7}{*}{ Primary School } \\
\hline & Primary School & 1,08 & & \\
\hline & Middle School Diploma ("Gymnasio") & 1,36 & & \\
\hline & High School Diploma & 1,48 & & \\
\hline & $\begin{array}{l}\text { TEl graduate } \\
\text { (Technological Educational Institute) }\end{array}$ & 1,13 & & \\
\hline & University Degree ("AEI") & 1,53 & & \\
\hline & Postgraduate degree (M.Sc., Ph. D etc.) & 1,33 & & \\
\hline & *Basic Compulsory Education & 1,24 & & Basic Compulsory \\
\hline & *Higher and Tertiary Education & 1,43 & & Education \\
\hline \multirow{7}{*}{ Employment } & Employer/Self -Employed/ Own - account worker & 1,47 & \multirow{7}{*}{0,04} & \multirow{7}{*}{$\begin{array}{l}\text { Unpaid Employee of family } \\
\text { business or farm }\end{array}$} \\
\hline & Employee / Daily wager & 1,40 & & \\
\hline & Unpaid Employee of family business or farm & 1,20 & & \\
\hline & Unemployed or temporarily out of work & 1,31 & & \\
\hline & Housewife & 1,32 & & \\
\hline & Pupil/Student/Soldier & 1,71 & & \\
\hline & Other ( e.g. Renter ) & 1,27 & & \\
\hline \multirow{4}{*}{ Months of Unemployment } & $(0-6)$ & 1,5 & \multirow{4}{*}{0,04} & \multirow{4}{*}{ Over 2 years } \\
\hline & $(6-12)$ & 1,5 & & \\
\hline & $(18-24)$ & 1,4 & & \\
\hline & Over 2 years & 1,34 & & \\
\hline \multirow{4}{*}{$\begin{array}{l}\text { Employer/Self-Employer/ Worker } \\
\text { for your own account }\end{array}$} & $\begin{array}{l}\text { Freelance (doctor, lawyer, engineer, architect, economist, } \\
\text { accountant, business consultant, etc.) }\end{array}$ & 1,57 & \multirow{4}{*}{0,03} & \multirow{4}{*}{ Farmer/ breeder/ fisherman } \\
\hline & Farmer/ breeder/ fisherman & 1 & & \\
\hline & $\begin{array}{l}\text { Professional/ } \\
\text { handicraft owner/ } \\
\text { street vendor }\end{array}$ & 1,40 & & \\
\hline & Owner of company/ entrepreneur & 1,60 & & \\
\hline
\end{tabular}

As shown in Table 3, during the period of "Economic Crisis" in Greece, the persons who have suffered the most of "Insult to Dignity" are women, in the age group (55- 65+) years old, those who are divorced or separated, those with a lower level of studies and especially those who have graduated only from Primary School. In addition, people working in the primary sector, who are working without pay in the family business or on the family farm and especially the long-term unemployed.

In an effort to identify the impact of the "Economic Crisis" at a social level and whether it has affected the participants' social and economic activity and their daily life in such a way that they feel "their Dignity Insulted" it was found that they have enormously influenced the following:

Table 4: Means Deviation Test (T-test) - Dimensions

\begin{tabular}{|c|c|c|c|}
\hline \multicolumn{4}{|l|}{ Means Deviation Test (T-test) } \\
\hline Enormous "Insult to Dignity" & Percentage of total & Mean & $\mathbf{P}$ \\
\hline Suicidal Tendencies & $11 \%$ & 1 & 0,000 \\
\hline Income & $84,6 \%$ & 1,03 & \multirow{4}{*}{0,05} \\
\hline Living Conditions & $68 \%$ & 1,04 & \\
\hline Health Condition & $57,6 \%$ & 1,04 & \\
\hline Social Exclusion & $27 \%$ & 1,10 & \\
\hline
\end{tabular}


According to Table 4, the participants have suffered an "Insult to Dignity" to a great extent due to the "Economic Crisis" in relation to their income, living conditions, health status and the social exclusion they have sustained, while it is considered important that all these parameters/factors contribute to suicidal ideation.

- The Coefficient of Determination or $\mathbf{R}^{2}$ (R-Square) explains the percentage of variance of the dependent variable that is due to the influence of the independent one/variable giving thus the opportunity to evaluate the significance in greater depth and the value of the latter, as a predictor of the former, since it can evaluate this contribution as a function of the "simultaneous" participation - contribution and other variables (Emvalotis et al., 2006). More specifically, according to Table 5, the total variance of "Insult to Dignity" as the dependent variable was found to be due to the following independent variables:

Table 5: Coefficient of Determination $\mathrm{R}^{2}$

\begin{tabular}{|c|c|c|c|}
\hline \multicolumn{4}{|c|}{ Coefficient of Determination $R^{2}$} \\
\hline \multicolumn{2}{|l|}{ Variables } & \multirow[t]{2}{*}{$\mathbf{R}^{2}$} & \multirow[t]{2}{*}{ Sig. F Change } \\
\hline Dependent & Independent & & \\
\hline \multirow{5}{*}{$\begin{array}{l}\text { "Insult } \\
\text { to } \\
\text { Dignity" }\end{array}$} & Economic Crisis & 0,250 & 0,000 \\
\hline & $\begin{array}{l}\text { Do not seek care because of economic } \\
\text { weakness }\end{array}$ & 0,190 & 0,000 \\
\hline & Lack of Money & 0,123 & 0,016 \\
\hline & $\begin{array}{l}\text { Living Conditions } \\
\text { Income }\end{array}$ & 0,605 & 0,000 \\
\hline & Months of Unemployment & 0,219 & 0,005 \\
\hline
\end{tabular}

As shown in Table 5, 25\% of the total variance of "Insult to Dignity" is due to "Economic Crisis", while $60.5 \%$ is due to the cut of "Incomes" as a result of the latter.

The Regression Analysis is used to predict the values of certain variables providing the opportunity of taking account of more than two independent variables. Based on this analysis, a linear relationship between the dependent and independent variable can be verified. In simple terms it is symbolized by the function: $\hat{Y}=a+b$ $X$, while in the case of multiple regression analysis the equation is: $Y i=a+b 1 * X 1=b 2 * X 2+\ldots+b v * X i$. That gives information about the percentage of the variation interpreted by all independent variables which have taken part in the regression process, but gives no information on the contribution of each individual variable. The independent variable is represented by $X$ and $\hat{Y}$ is the dependent variable, which is a function of a slope coefficient (b) and a constant (a). The constant $a$ in the function is the point at which the prediction's straight line intersects with the vertical axis, while the regression coefficient $b$ or slope of the line gives information about the size of the prediction and the type of relationship between the two variables. The coefficient $b$ i.e. displays the variation of the dependent variable when the independent is changed by one unit. A significant slope means a significant prediction. Therefore, the higher (and positive) the coefficient $b$, the more statistically significant the prediction of the independent in relation to the dependent variable (Nova - Kaltsouni, 2006). In the following Table, the existence of a linear relation $(\hat{Y}=a+b X)$ was identified between the dependent variable "Insult to Dignity" $(\hat{Y})$ and the following independent variables $(X)$ : 
Table 6: Regression Analysis

\begin{tabular}{|c|c|c|c|c|c|}
\hline \multicolumn{6}{|c|}{ Regression Analysis } \\
\hline \multicolumn{2}{|l|}{ Variables } & \multirow{2}{*}{$\begin{array}{c}\text { Linear } \\
\text { Equation } \\
(\mathrm{Y}=\mathrm{a}+\mathrm{b} \mathrm{X})\end{array}$} & \multirow{2}{*}{$\begin{array}{l}\text { std } \\
\text { beta }\end{array}$} & \multirow[b]{2}{*}{$\mathrm{p}$} & \multirow{2}{*}{ Coefficient b } \\
\hline Dependent & Independent & & & & \\
\hline \multirow{6}{*}{$\begin{array}{l}\text { "Insult } \\
\text { to } \\
\text { Dignity" }\end{array}$} & Economic Crisis & $Y=a+0,433 X$ & 0,433 & 0,000 & $\begin{array}{l}\text { Positive and Moderately } \\
\text { Significant }\end{array}$ \\
\hline & $\begin{array}{l}\text { Do not seek care because of economic } \\
\text { weakness }\end{array}$ & $Y=a+0,326 X$ & 0,326 & 0,000 & \multirow[t]{2}{*}{$\begin{array}{c}\text { Positive and } \\
\text { Moderately Significant }\end{array}$} \\
\hline & Lack of Money & $Y=a+0,310 X$ & 0,310 & 0,004 & \\
\hline & Living Conditions & $Y=a+0,217 X$ & 0,217 & 0,008 & Positive and Weakly Significant \\
\hline & Income & $Y=a+0,608 X$ & 0,608 & 0,000 & Positive and Strongly Significant \\
\hline & Months of Unemployment & $Y=a+0,468 X$ & 0,468 & 0,005 & Positive and Moderately Significant \\
\hline
\end{tabular}

As follows there is a linear equation (relation) between "Insult to Dignity" and "Economic Crisis" ( $Y=a+0.433$ $\mathrm{X}$ ) where the coefficient $\mathrm{b}$ is positive and moderately significant and between "Insult to Dignity" and "Income" $(Y=a+0.608 \mathrm{X})$ where the coefficient $\mathrm{b}$ is positive and strongly significant.

\section{Conclusions}

As evident from the research part, during the period of economic crisis and the implementation of structural measures in Greece, a large portion of the population has suffered an insult to their dignity.

Of this research, the population that has suffered the most dramatic repercussions of the crisis are women and those who belong to the age group (55- 65+) years old (Eurostat,2012b,2012c ). Those who have a lower level of education, especially those who hold an Elementary School certificate, and those employed in the primary sector of production have more intensely suffered a deterioration of living standards (Caritas Europa, 2013). Regarding marital status it was shown that those who are divorced or separated are facing major problems, whereas similar situations are being faced by married people due to indebtedness and inability to respond financially to the increased demands of the household. Clearly, the results will be more burdensome for those households having members who are unemployed or workers of low labor-intensity (Eurostat, 2012a). Unpaid employees of a family business or farm have sustained a greater degree of insult to their dignity in relation to their incomes and living conditions. At the same time, high unemployment rates, informal and uninsured labor, as well as significant reductions that have been made in social benefits, minimum wage and unemployment benefits can justify the great "impoverishing" or "poorness" and marginalization suffered by the unemployed and especially the long-term unemployed and the chronically ill (Eurostat, 2012a).

As signified, an enormous insult to dignity is associated with the incomes, living conditions, health status and social exclusion that they have experienced as a result of the economic crisis of recent years. It is therefore confirmed, both in research and in theory, that a large part of the Greek population has been led not only to the elimination of a minimum acceptable standard of living in the country (European Council, 1975), but also to acute deprivation of basic human needs (Balourdos, 2012) and to decline on the labor market and the health system, which have the potential to contribute to the political, economic, social and interpersonal participation and integration of people in society (Feronas, 2004).

The insult to dignity deprives individuals of participation in the economic, social and political life of the country (Andriopoulou et al., 2013). It even takes away their equal opportunities, decent living, development of their personality and exercise of their fundamental rights (Retinioti et al., 2010). This, therefore, raises issues of distribution, social justice and consolidation of fundamental human rights.

Both the theoretical and the research level demonstrate the Council's recommendation and the European Parliament's resolution that a reasonable minimum income is indispensable for the decent life of an individual, which along with social participation contributes to ensuring citizens' welfare and ultimately to the formation of a democratic society (Ktistaki, 2012).

The citizen claims from the state a minimum social security level which not only ensures the sustenance of the individual, covers basic needs and prevents severe poverty, but also allows decent living, development of his personality 
and exercising of fundamental rights (Ktistaki, 2012). It requires from the state to respect and protect human value when threatened or attacked. It calls for taking all those "positive measures" to ensure an environment that allows him to enjoy his rights (Pantazis, 2008) and not attack the manifestation of human dignity, since this is the core of all rights (Tsevrenis, 2012).

For reasons of public interest or invoked emergency, there is a dilemma between economic sustainability (economic collapse or not) and social effectiveness of the welfare state, in favor of the former. However with the extension of the legal concept of "public interest", which is now viewed as superior or overriding to interest, this cannot be challenged to such an extent as to be able to justify extreme restrictions on our constitutional statutory social rights. The existence of the welfare state is associated with a more equitable distribution of national income and the idea of social justice and solidarity to provide rectification of injustices and inequalities and redistribution of social resources (Ktistaki, 2012). Otherwise, it is not only the dignity of the citizen that is being threatened, but also the social cohesion of Greek society.

However, despite whatever results emerge at the theoretical and research level, it should not be ignored that behind the statistics are human beings, who are born free and equal in dignity and rights. There should be an effort to render their human rights - especially those of the weak - as visible lessons by means of potent indicators, so that they may be used to continuously improve human rights policies and implement systems that will bring about positive changes in people's lives.

\section{References}

Andriopoulou, E., \& Tsakloglou, P. (2010). Dynamic Analysis of the Effect of Poverty in Greece. In: Centre for Economic and Social Developments. Research Unit of Social Policy, Poverty and Inaequalities. Study 4. December 2010. Athens: INE - GSEE. (In Greek).

Andriopoulou, E., Papadopoulos, F., \& Tsakloglou, P. (2013). Poverty and Social Exclusion in Greece : Overlap and Differentiations. In: Observatory of Economic and Social Developments. Research Group of Social Policy, Poverty and Inequalities. Study 25. September 2013. Athens: INE - GSEE. (In Greek).

Arendt, H. (1956/2006). Elemente und Ursprünge totaler Herrschaft. 11. München: Auflage.

Balourdos, D. (2012). Poverty in Greece : trends, challenges and policies. In: D. Balourdos, \& M. Petraki (Eds.), New Poverty and Social Exclusion. Fighting Policies and Establishment of Minimum Guaranteed Income. Special Session of the Standing Committee on Social Affairs. Senate House Hall.15 February 2012 (pp. 21-55). Athens: Greek Parliament. (In Greek).

Bourikos, D., \& Sotiropoulos, D. (2014). Economic Crisis, Social Welfare and Civil Society. The impact of the economic crisis on the formal and informal civil society actors in the field of social solidarity and new constraints of social citizenship in the period of economic crisis. Athens: ELIAMEP. Observatory for Crisis. (In Greek).

Caritas Europa. (2013). The impact of the European Crisis. A study of the impact of the crisis and austerity on people with a special focus on Greece,Ireland, Italy,Portugal and Spain. Retrieved 5/12/2015, from Caritas Europa: http://www.caritas.eu/sites/default/files/caritascrisisreport_web.pdf

Chamber of Viotia. (2012, January 10). Key Financial Indicators. AvákTnon 25/05/2015, from Chamber of Viotia: http://www.viotiachamber.gr/viotia/articles/article.jsp?context=103\&categoryid=607\&articleid=605

Comisión General de Justicia y Paz. (2014, October). Protecting Human Dignity at a Time of Economic Crisis: Final Statement of the International Workshop of Justice and Peace Europe. Retrieved 22/11/2015, from Comisión General de Justicia y Paz: http://www.jupax-europa.org/en/themes-and-activities/annual-meetings/JP_Europe_Final_Declaration_IW.pdf

Darviri, C. (2009). Research methodology in health. Athens: Medical Publications P. Ch. Pashalidis. (In Greek).

Delikonstantis, K. (1995). Human rights, the Western Ideologiew or Ecumenical ethos? Thessalonica. (In Greek).

Emvalotis, E., Katsis, A., \& Sideridis, G. (2006). Statistics Educational Research Methodology. Ioannina. (In Greek).

European Council. (1975). Council Decision of 22 July 1975 concerning a programme of pilot schemes and studies to combat poverty. No 75/458/EEC. In: Official Journal of the European Communities, L199. Brussels: European Council.

European Parliament. (2014, February 21). Report on aspects of employment and social aspects of the role and work of Troika (ECB, Commission and IMF) for the euro area countries subject to the fiscal adjustment program. Retrieved 13/10/2014, from European Parliament: http://www.europarl.europa.eu/sides/getDoc.do?pubRef=-//EP//TEXT+REPORT+A7-2014-0135+0+DOC+XML+V0//EL

European Parliament. (2013, June 18). Report on the impact of the crisis on the access of vulnerable groups to health care. Retrieved 31/10/2014,from European Parliament:http://www.europarl.europa.eu/sides/getDoc.do?type=REPORT\&reference=A7-20130221 \&language $=\mathrm{EL}$

Eurostat. (2012a). November 8). Headline Targets.t2020_50,51,52,53. Retrieved 5/12/2015, from Eurostat: http://epp.eurostat.ec.europa.eu/portal/page/portal/europe_2020_indicators/headline_indicators

Eurostat. (2012b). At-risk-of-poverty rate of elderly people, by sex.tsdde320. [Online] (Updated 5.11.2012). Retrieved 5/12/2015, from Eurostat: http://epp.eurostat.ec.europa.eu/tgm/table.do?tab=table\&plugin=1\&language=en\&pcode=tsdde320

Eurostat. (2012c). At Risk of Poverty Rate by Detailed Age Group , tessi120 [Online] (Updated 9.11.12). Retrieved 5/12/2015, from Eurostat: http://epp.eurostat.ec.europa.eu/gm/table.do?tab=table\&init=1\&language=en\&pcode=tessi120\&plugin=1 
Feronas, A. (2004). Poverty and Social Exclusion in Europe and Greece:Concepts,perceptions, policies. Athens-Komotini: Sakkoulas. (In Greek).

Frazer, H., \& Marlier, E. (2012). 2011 Assessment of Social Inclusion Policy Developments in the EU. January 2012. EU Network of Independent Experts on Social Inclusion.

Gewirth, A. (1992). Human Dignity as the Basis of Rights. In: M. Meyer, \& W. Parent (Eds.), The Constitution of Rights (pp. 10-28). London.

INE - GSEE. (2013). The Greek economy and employment. Annual Report 2013. Athens: INE - GSEE. (In Greek).

Kemp, P., Rendtorff, J., \& Johansen, N. (Eds.). (2000). Bioethics and Biolaw, Vol. Il: Four Ethical Principles. Copenhagen.

Kentikelenis, A., Karanikolos, M., Papanicolas, I., Basu, S., McKee, M., \& Stuckler, D. (2011, October 22). Health effects of financial crisis: omens of a Greek tragedy. Lancet, Volume 378, pp. 1457 - 1458.

Ktistaki, S. (2012, July - August). The impact of the Economic Crisis on Social Rights. Inspection of the Law of Social Security (Epitheorisis Dikaiou Koinonikis Asfalisis). Year ND'. Isuue Number 4/635. pp. 481 -506. Retrieved 14/10/2014, from Inspection of the Law of Social Security (Epitheorisis Dikaiou Koinonikis Asfalisis): http://constitutionalism.gr/site/wpcontent/mgdata/pdf/edka2012.pdf

Lamprinidis, G., Maniatis, T., Mpasiakos, G., Economou, A., Papadopoulou, M., \& Passas, K. (2010). Empirical Approach to Absolute Poverty in Greece : The needs for housing, food, clothing, footwear, transportation. In: Observatory of Economic and Social Developments. Research group of Social Policy, Poverty and Disparities .Studies 5. December 2010. Athens: INE - GSEE(In Greek).

Nova - Kaltsouni, C. (2006). Empirical Research Methodology in Social Sciences . Data Analysis using SPSS 13. Athens: Gutenberg. (In Greek).

Pantazis, V. (2008). Education for Human Rights. Development of "Human Rights" in educational practice. Retrieved 3/02/2015, from Review of Educational Affairs, Issue 14, p. 107 - 122: http://www.pi-schools.gr/download/publications/epitheorisi/teyxos14/107122.pdf

Pantazis, V. (2013). Absolute and Relative Poverty. 4 January 2013. Avgi . (In Greek).

Paraskevopoulos, I. (1993). Methodology in Scientific Research, Vol. 2. Athens. (In Greek).

Phillips, B. (2011). Dignity and Human Rights. A missing dialogue? Bellagio: PWESCR.

Retinioti, A., \& Mantziou, I. (2010, December). The access of the poor and socially excluded groups living in the center of Athens city, in the health, education and work. Social Service of Medicines De Monde. Retrieved 3/07/2014, from Doctors of the World (Medicines de Monde): http://mdmgreece.gr/attachments/116_Ek8esh_Greek.pdf

Social Protection Committee. (2012). The Social Impact of the economic crisis and ongoing fiscal consolidation:Third Report of the Social Protection Committee (2011). Directorate-General for Employment, Social Affairs and Inclusion.

Thielen, H. (2000). Menschenwürde, Armut und Befreiung. UTOPIE kreativ, Heft 119 , pp. 853 - 864.

Tsevrenis, B. (2012). Human Didnity: The functional use of the regulatory scope in the legal reasoning. Doctoral Thesis. Athens Thessaloniki: Sakkoulas. (In Greek).

Vamvoukas, M. (1991). Introduction to Psychoeducational Research and Methodology. Athens: Grigoris. (In Greek).

Watts, H. W. (1968). An economic definition of poverty. In: D. Moynihan (Eds.), Understanding Poverty. New York: Basic Books.

Wildfeuer, A. (2002). Menschenwürde -Leerformel oder unverzichtbarer Gedanke? In: M. Nicht, \& A. Wildfeuer (Eds.), PersonMenschenwürde - Menschenrechte im Disput (pp. 19 - 116). Münster. 